\title{
Habituation Model of Discipline Value in Salafi Pesantren's Student as Efforts to Strengthen the Character of the Nation in the Global Era
}

\author{
(A study on Citizenship Education Development)
}

\author{
Sri Wahyuni Tanshzil \\ Departemen Pendidikan Kewarganegaran \\ Universitas Pendidikan Indonesia \\ Bandung, Indonesia \\ sriwahyunitanshzil@upi.edu
}

\begin{abstract}
The character problems in the next generation has become one of the central problems of almost all countries in the world on the last three decades. The intensity of global currents without value filters and norms is a major contributing factor to the collapse of the nation's morale. Therefore, the strengthening of character education in all sectors, formal, informal, nonformal and implemented by all elements becomes a necessity. One of them is implemented through habituation process of character value. The purpose of this research is to find out how the Habituation Model of Discipline Value in Indonesia Salafi Pesantren's Student as Efforts to Strengthen the Character of the Nation in the Global Era. This research uses qualitative approach with analytical descriptive method. With the subject of the research are Leader, Teachers, and students at Pondok Pesantren Salafi in Tasikmalaya. Data collection techniques used observation, interview, documentation study and literature study. The results showed that: 1) Habituation of Discipline values using the comprehension approach, pass through habituation in the learning process, extracurricular, the implementation of worship as well as in social intercourse. While the habituation method is done through the provision of stimulus through the rules and role models teachers, the emergence of responses, actions and reinforcement of the action.
\end{abstract}

Keywords-habituation of character education; discipline; character of the nation

\section{INTRODUCTION}

A problem deals with the future generation's character has become the critical issue in all over the world for the las three decades. The rapid development of the globalization with the lack of the means of selecting values and norms has become the main cause of moral depravity of a nation. The low quality of the existing education also contributes to this problem. In fact, the quality of a country can be reflected on its human resource [1]. One of the international organizations, that is United Nations Development Programme (UNDP), conducted a survey and showed the ranking of a country according to Human Development Index (HDI). Based on HDI report, Indonesia ranks the lowest position of the other countries such as Singapore, Malaysia, Thailand, Brunei Darussalam, and
Philippines. Whereas, World Education Ranking published by Organization for Economic Co-operation and Development (OECD) shows that the Indonesian education quality is ranked $57^{\text {th }}$ out of 65 countries. This condition reflects a poor education condition amidst abundance of natural and human resources.

Moreover, the moral depravity of the nation today is embodied in the forms of a corruption practice, the inter-ethnic conflicts, the assassination of religious leaders, the increase of crime and sexual abuse, the decline of work ethic, and the increase of brawls among schools or campus. Everything happens with a reason. Every occasion is the result of an educational process either in the forms of formal, informal, or non-formal. The education which still considers the cognitive aspect as the main guideline in an instruction has yet to reach the affective and psychomotor fields - for example, Kerr [2] investigates the learning of Citizenship education in the Southeast Asia considered to be in the minimum category, where one of the indicators was the instruction dominated by the cognitive achievement. The contribution is realized by focusing on moral knowing, loving good (moral feeling) and moral action achievements [3]. Philosophically speaking, "education without character, this is sins the basis for misery in the world, the essence of education is to recognize truth. Let your secular education go hand in hand with spiritual education" [4]. Based on this statement, creating an education which can produce peace, tolerance, respect, and ability to embody the society's values as an Indonesian needs a support from all elements; that is from family, society, government, and school.

Citizenship education as one of the core subjects in developing and strengthening a nation's character plays an important role; either in a formal or non-formal way. Cogan [5], states that Citizenship education does not only refer to a subject taught in schools but also learning experience outside schools (non-formal / informal educational institutions). The vision of Citizenship education is realized through three different roles and functions. They are (1) curricular program in the formal and non-formal educations, (2) socio-cultural 
action program in the social context, and (3) field of scientific study in the educational discipline context in social science. As a socio-cultural program, Citizenship education contributes to the realization of goals, belief system / value, consept, principls, and democraxy in the context of madani Indonesian development [6].

Pesantren is defined as one of the integral parts of the socio-cultural based enducation environment due to its rapid development in the Indonesian people's life. Pesantren is originally considered as the educational institution in Indonesia which develops to be one of the Indonesian heritages, and supports the Indonesian life [7]. Pondok Pesantren is seen as an Indonesian educational institution applying the habituation model and focusing on religious values and the nation values. Thus, pondok pesantren can be treated as a functional institution used to develop the Indonesian nation's characters.

During the Dutch colonialism, pesantren became the educational institution, that supported the Indonesian people and merged into the people's life. Pesantren was the main determiner of the Islamic Empire's characteristic in Nusantara [7]. Since pesantren produced many leaders at that time, it could meet the people's need (in this case is the knowledge) to master a certain field where the people could improve their religious and social-cultural quality lives so that they could reach an important position in a diverse nation with high dignity.

Based on the statement above, this study investigates a model to develop character surrounding pesantren, especially the habituation model implemented to build a discipline value of the students as an attempt to strengthen the future generations' character in the Global era.

\section{THEORETICAL}

\section{A. The Nature of Discipline}

Discipline is defined as conscious condition of a person to obey rules or certain values to live in a certain environment [8]; that is, by following the given patterns in the environment. The process of the character or discipline value formation is attributed to a guiding process, habituation, stimulus, and strengthening. The repetition will engender a habit and an individual who has the habit will feel guilty if $s($ he) does not do the habit.

Therefore, the process of guiding the discipline character should consider a) proper habituation $\backslash \backslash$, b) positive example (imitation), c) appreciation (suggestion and identification), d) command, prohibition, and punishment (motivation), and e) song to strengthening the students' habit. There are some forms of strengthening that can be applied to maintain the discipline character building. They are a) rules, b) punishment, c) rewards, and d) consistency [9].

A discipline character has several functions in educating a child. Those are first, discipline is needed in the socialization process; that is, a child will learn the prevailed standards in a social system. Second, discipline is needed to build the maturity; that is, a child will build personality, trustable, confident, self-control, and diligent. These aspects appear spontaneously. Yet, they exist as the response to the demand and sustainable social expression. Third, discipline is required to internalize the standard of moral and responsibility. This standard is not only being centralized but also embodied in the form of external behaviour; it is even made to guarantee the endurance stability of the social system. Fourth, discipline is needed for the children's emotional security, especially to give help the children overcome confusion and fear towards a behaviour [9].

\section{B. Habituation in the Reinforcement Process of Character Education}

Habituation refers to a process that creates persistent-life situation comprising varieties of reinforcement that enables the students -whether in schools or society - to get themselves used to acting according to the given values and make the elements of the values which have been internalized and personalized through heart, thought, exercise, and senses as their character [10]. Habituation becomes the dominant factor in making the process of the students' character reinforcement successful [11].

Character itself can be defined as "to mark" such as on a craving. Someone's character is the unremovable consistency mark and predictability [12]. Character as an individual's general approach to the problems and responsibility of the social life is the response to the today condition that is supported by the emotional reaction towards the other's problem, the achievement of the proportional performance, knowledge of the social convention, and the construction of personal values [13]. Hence, the design of character education is not implemented using a short cut; it needs thoughtful, systematic, and continual process. It covers a development involving moral knowing, moral feeling, and moral action [3].

From Indonesian main design of the character education shows that habituation and intervention are two approaches that are designed thoughtfully to support the process of the character building and reinforcement can optimally run. These two approaches are used based on the premier plan taken and dug as well as crystalized from various sources. The sources are (a) philosophical source which is based on religion, Pancasila, Constitution 1945, Act 20 of 2003, (b) theoretical source taken from educational theory, physiological theory, theoretical source, value-moral theory, and socio-cultural theory, and (c) empirical theories, in the forms of an experience and the best practice of figures, eminent education, pesantren, and cultural group [10].

There are the basic principles that have to be effectively running in the process of the character education building [14]. The principles are then adopted by Character Education Partnership. The first principle states that a good character is built based on the core ethic values, such as caring, honesty, justices, responsibility, and respect. The second principle states that a program should teach the core values in a holistic way using the cognitive, affective, and behaviour components by involving schools. The process of involving the schools can use an intentional way, proactive way, and comprehensive way (principle 3). The forth principle explains the existence of a community in schools that takes care of intentional way, 
proactive way, and comprehensive way and the commitment of the students to participate in doing moral actions, for example, having a community service program (principle 5). An effective character education does not omit the academic curriculum that is strict and challenging (principle 6). This principle grows an intrinsic motivation to do a right thing by building trust and respect; encouraging to have autonomous feeling; and building common norm through dialogue, learning-teaching activities, and democracy-consensus (principle 7). In addition, the core values that liven up the students' life should involve schools' staffs (principle 8). Next, to start the character education, we should produce the same educational leadership that can establish rules as the long-term support taken from the initiative (principle 9); principle 10 explains the involvement of family and community stakeholders; and principle 11 explains the commitments towards the ongoing assessment and evaluation [12].

\section{METHOD}

To discuss how the habituation model of discipline value in building characters in the Global era implemented in the pesantren, this study uses a qualitative approach along with a case study method. This method is used to investigate a habituation model of a discipline value in building a character in the global era through a program, event, activity, process, or a group of individuals that is limited by time and event. Furthermore, this approach is selected because the researcher is able to discover the answer for some of the research focus; that is, regarding the applicable approach and method in implementing the habituation model of discipline values in a pesantren.

This study is conducted in Tasikmalaya, precisely in a pesantren called pondok pesantren Salafi, K.H. Zainal Mustofa's pesantren. The selection of this pesantren for this study is based on some reasons; they are 1) this pesantren is the icon of the knowledge development as well as the people's character development in Tasikmalaya regency, and 2) this pesantren has produced some important figures. The research subjects are (1) the leader of the pesantren, (2) the teachers, (3) the students (girls and boys), (4) five student, (5) the students' parents, (6) three people living around the pesantren. The data collection is conducted through 1) interview toward some respondents, 2) observation on the activity conducted in the pesantren, either in the form of program, activity, process, and a group of people, and 3) documentation related to the this study and relevant literature reviews taken from both international and national journals.

The data are analysed using Milles and Huberman's model [15] where the conclusion is made through three processes that are simultaneously conducted, starting with the data reduction, data presentation, and data verification.

\section{RESULT AND DISCUSSION}

\section{A. The Habituation Approach of Discipline Values Pondok Pesantren Salafi K.H. Zainal Mustafa is Comprehensively Conducted}

Habituation is considered to be as an important thing in building an individual's character. However, tagging a value to be an individual's character will take times. Character cannot be taught by any ethical theory automatically because a theory cannot produce an experience that can unite the eternal happiness of an individual when s(he) has the virtue [16]. A character building cannot be carried out only using a theory in a short time without any process to "do a certain action". In addition, Aristotle states "we must have been brought up in a certain way from childhood onwards, as Plato says, so as to delight in and be distressed by the things we should; this is what the correct education is. As further support for connecting education with pleasure and distress, Aristotle notes that we often resort to "the practice of forcible correction which takes place through pleasure and pain" (NE 1104b, 16-17)". A moral development should be created in a certain way since the childhood until a complex process -i.e. where pain and pleasure- is reached. The pain and pleasure can be the stimulus for someone to act according to the existing values and norms. In this case, the habituation condition appears as a permanent and automatic process realized through the repetition [17].

Regarding the educational unit, including in Pondok Pesantren K.H.Zainal Mustofa, habituation becomes the eminent activity used to build the students' behaviour (ahlaq), especially the character building. The educational process and character building consist of four stages that the students should pass [18]. They are (a) habituation as the early development of the students' character; (b) understanding or knowledge of the accustomed values and norms; (c) the action implementation and the students' action in daily life; and (d) interpretation as the students' reflection through all assessments about attitude and behaviour that they understand and do as well as the effects on and advantages for their lives and the other's.

Some of the research participants stated the statements when they were interviewed in the Pondok Pesantren. Where the habitation of discipline character is conducted continuously and comprehensively in the pesantren; it starts from the habituation to do the instructional process in a mosque or madrasah (school), the habituation to pray together, the habituation to do an extracurricular activity, the habituation to manage social manners, the habituation to act politely, the habituation to use their own properties, and the habituation to use their times. This statement shows that building and developing a character will be related to a certain existing environment [19]; the environment that can support all created activities as well as the certain condition that can support the development of the students' character. A character is not a collection of habits and separated ideas. It is a small lesson teaching that a good principle cannot be effectively working if not being integrated to the individual's belief system about the individuals themselves, the other, and the people's good. 
Education using a habituation process will be an effective way to build iman and produce deed to implement a rightassumed norm [20]. The core of this process is the repetition of doing the same habits to build and develop an individual's character [21]. Each habitation will be explained as follow. First, the habituation to do the instructional process in a mosque or madrasah (school); Second, regarding the the habituation to pray together; Third, the habituation to do an extracellular activity; Fourth, the habituation to manage social manners; Fifth, the habituation to act politely and pay attention to their manners; Sixth, the habituation to mingle with peers; Seventh, the habituation to use their own properties: Eighth, the habituation to use their times.

All habituation activities in Pondok Pesantren K.H. Zainal Mustofa as the attempt to build the students' discipline character are defined as the condition in the educational unit which is the situation that is created and designed carefully. Through these habituation activities, the students are expected to be able to act wisely or to have the virtue [22] which are based on the prevailing norms and values. They are also expected to be able to feel the pain or punishment for their mistakes.

Regarding the learning context (above), the habituation of discipline value is based on the awareness. The awarenessbased learning condition should be built through three reviewing stages; they are 1) accommodation stage shows the students are given a chance to learn and internalize the moral values, 2) assimilation stage shows the value internalization into the other values that have been existed, 3) equilibration stage shows the attempt to standardize the value as a new value system [23]. The habituation becomes a key to build a value / character as an American philosopher and psychologist, William James stated in his theory Iron Law of Habit [24]. The key point of the theory is education is the beginning habituation process to drill an individual to be a part of a perfect society. James sees that the key point of the education is the habits to prepare individuals to live their daily lives [24]. There are three basic strategies according to James's point of view [21] to make habituation success. First, the habituation should be carried out carefully so that the students can receive it well. Second, the habituation should be intensely conducted so that the students can understand the value and implement it as what we expect. Third, the habituation should be conducted as soon as possible.

Such condition will be lasting for a long time with the full support from the related elements such as society, government, parents, community, religious leaders, etc. eventually, the students will get used to doing good action. Furthermore, this condition will build the excellent character, one of them is discipline character.

\section{B. The habituation Method of Discipline Values in Pondok Pesantren Salafi K.H. Zainal Mustafa}

Character can be created through the process of habituation [22]. The good virtue (character value) might appear if the value itself has been realized (put in the action). An individual will become a religious because $s($ he) has already practiced things that religious person does. An individual can become an independent because $\mathrm{s}(\mathrm{he})$ has already practices independent thing. Furthermore, Aristotles says, "Just as individuals become 'builders by building and harp players by playing the harp, so also, then, we become just by doing just actions, temperate by doing temperate actions, brave by doing brave actions" [12].

Based on the meaningful quotation on character and habituation that Aristotles says, it could be said that habituation plays an important role in building character. Habituation is carried out by creating a certain condition, where a child can experience a good action (certain values). The terms for building habituation are a) stimulus, b) response, c) action / experience [25]. If those terms are filled already, the next steps that can be followed up are a) focusing, b) doing/practicing and repeating, and c) doing the job automatically.

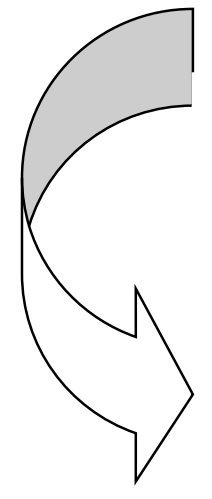

$\begin{array}{ll}\text { 1. } & \text { stimulus } \\ \text { 2. } & \text { response } \\ \text { 3. } & \text { action }\end{array}$

1. Focusing

2. repeating and practicing

3. doing the job automatically

Fig. 1. Habit Formation [25].

The statement above describes how a process to build a value / character in a certain environment which starts with a stimulus giving and then followed by the production of a response and ends with a certain action formation. Based on the data, there are some stages used to build a discipline character in Pesantren K.H. Zainal Musthafa. They are 1) stimulus giving through the rules that prevail in the pesantren and through teachers as the role model. The competition is related to intention, motivation, and attitude of the teacher. As the result, the teacher's attitude becomes motivation for the students to uphold the discipline value in their lives; giving rewards and punishment, as well as advices; b) response from the students, starting from knowing the process understand it; c) the emergence of action (character) which is in the form of the values of good virtue that are based on the prevailing norm and automatic in nature.

The next stage is reinforcing or strengthening the good virtue/values/characters through repetition and practices that takes time which will lead to the automatic action (character). In this stage, the students have already understood that their responsibility is a necessity which is produced through a certain process [26]. This condition is comprehensively created in a pondok pesantren, either in the learning environment, social manners, extracurricular activities, etc.

With the condition, habitation becomes the model to strengthen discipline characters (independent and the other excellent character) in pondok pesantren Salafi yaitu salah satunya Pondok Pesantren K.H. Zainal Mustofa, which 
nowadays the pesantren has become one of the educational institutions in Tasikmalaya. The pesantren is seen as the base for the ideal education because it becomes the base spreading not only knowledge but also value, character, and leadership pillars for the next generation [27]. The pesantren can produce the future generations with good knowledge and good faith. According to the citizenship education, this condition is the one that can prepare, train, and build characters based on the Indonesian cultural values and Pancasila.

This condition is known as Citizenship Education. In board terms, Citizenship Education has function and role as (1) a curricular program both in formal and non-formal education, (2) socio-cultural action program in the context of the society, and (3) research object in social science. As the socio-cultural program, Citizenship Education gives the embodiment of ideals, belief system / value, concept, principle, and praxis of democracy in terms of the attempts to build the Indonesia society through the people's participation through a creative socio-cultural activity that in the end will lead to the development of moral and social commitment.

\section{CONCLUSION}

Based on the discussion above, some essential things related to the implementation of habituation model of discipline value in pondok pesantren salafi (K.H. Zainal Mustafa) are discovered. First, the implementation of the habituation model of discipline value uses a comprehensive approach in all existing segments and environments, either through the habituation in the instructional activity, extracellular, religious practice, and mingle with friends. Second, the implementation of the habituation model of discipline value is realized through some stages covering a) a stimulus through the rules in the pesantren, teachers' role model, rewards and punishments as well as the advices, b) the students' response, c) positive attitude, and d) the reinforcement of the action (it starts with the repetition and then turns to be a habit).

\section{REFERENCES}

[1] D. Keith, Human Behavior at Work; Organizational Behavior. New Delhi: Tata McGraw-Hill Publishing. 1990.

[2] K. David, Citizenship Education; an international comparison. London: Qualification and Curriculum Authority. 1999.

[3] L. Thomas, Educating for Character, How Our Schools Can Teach Respectand Responsibility. Bantam Books: NewYork. 1992.

[4] S. Sai, A Compilation of The Teaching of Sathya Sai Baba on Education. Sathya Sai Book Center of America. 2002.
[5] Winataputra and Budimansyah. Citizenship education : Konteks, Landasan, Bahan Ajar, dan Kultur Kelas. Bandung: Program Studi Pendidikan Kewarganegaraan SPs UPI. 2007.

[6] Winataputra, U. S., Jati Diri Pendidikan Kewarganegaraan Sebagai Wahana Sistemik Pendidikan Demokrasi. Disertasi Doktor pada SPS UPI Bandung: tidak diterbitkan. 2001.

[7] Dhofier, Z., Tradisi Pesantren studi pandangan hidup Kyai dan visinya mengenai masa depan Indonesia. Jakarta: LP3SE. 2011.

[8] T. Tulus, Peran disiplin pada perilaku dan prestasi siswa. Jakarta: Grasindo, 2004, 82.

[9] Darmawani, E. Model Investigasi Kelompok dengan Metode Sosiodrama untuk Meningkatkan Motivasi dan Disiplin Siswa SMA. Desertasi. Bandung: Universitas Pendidikan Indonesia, 2012.

[10] B. Dasim, Penguatan pendidikan kewarganegaraan untuk membangun karakter bangsa. Widya Aksara Press, 2010.

[11] U. Abdullah, Nashih. Tarbiatul Aulad Pendidikan Anak Dalam Islam. 2013.

[12] Lapsley and Narvaez. Character education. New York: Wiley Online Library. 2006.

[13] Hay, D.F., Castle, J., Stimson, C.A., \& Davies, L. (1995). The social construction of character in toddlerhood. In. M. Killen \& D. Hart (Eds.), Morality in everyday life: Developmental perspectives. (pp. 23-51). Cambridge, UK: Cambridge University Press.

[14] L. Thomas, "A comprehensive approach to character building in Catholic schools." Journal of Catholic Education 1. 2, 159-175. 2013

[15] Miles, M. B., Qualitative data analysis: An expanded sourcebook. sage, 1994.

[16] O'Leary, Paule. Ethical Habituation and Pleasure. Paideusis, Volume 16 2007. No. 1, pp. 41-45

[17] Wahyuningsih, The Development of Habituation Learning Model Based On Traditional Child Songand Movement Game to Create the Character of Early Age Children. Proceeding The 2nd International Conference On Teacher Training and Education Sebelas Maret University Volume 2 Number 12016 ISSN : 25002 - 4124, 2016.

[18] Kohlberg, L., Stages of Moral Development. Yogyakarta: Kanisius. (Textin Indonesian) 1992.

[19] K. Doni, Pendidikan karakter: Strategi mendidik anak di zaman global. Jakarta: grasindo 2007, 212-221.

[20] Ulwan, A. N., Pedoman Pendidikan Anak dalam Islam, (terj.). Semarang: CV. Asy Syifa'. 1993.

[21] Susanto, T., Intervensi coaching dan guidance dalam peningkatan ketrampilan hidup kesehatan reproduksi remaja di Kabupaten Jember. 2018.

[22] Aristotle, Nicomachean Ethics, trans. Christopher Rowe, 1104b 11-13 (hereafter cited in text as NE).

[23] P. Jean, "Introduction à l'épistémologie génétique." 1951.

[24] Gavin, W. J., William James, 1842-1910. The Blackwell Guide to American Philosophy 25, 101, 2004.

[25] Az-Zabalawi, Muhammad Sayyid M. Pendidikan Remaja antara Islam dan Ilmu Jiwa, Jakarta: Gema Insani, 2007.

[26] Hurlock, Elizabeth B. "Moral Development." 1956.

[27] R. Fathur, Sosiolinguistik: Suatu pendekatan pembelajaran bahasa dalam masyarakat multikultural. Graha Ilmu, 2013. 